\title{
PENGEMBANGAN MULTIMEDIA PEMBELAJARAN MENGGUNAKAN ADOBE FLASH MENGENAL KONSEP DAN LAMBANG BILANGAN PAUD
}

\author{
Nurdiansah Dwi Sasongko \\ Program Studi Pendidikan Anak Usia Dini Fakultas Keguruan dan Ilmu Pendidikan \\ Universitas Ma'arif Nahdlatul Ulama Kebumen \\ email : sahabatsasongko@gmail.com
}

\begin{abstract}
Abstrak: Pengembangan Multimedia Pembelajaran Menggunakan Adobe Flash Mengenalkan Konsep Dan Lambang Bilangan PAUD. Penelitian ini bertujuan untuk menghasilkan produk multimedia mengenal konsep dan lambang bilangan PAUD yang layak digunakan dalam proses pembelajaran. Kelayakan multimedia pembelajaran ditinjau dari aspek materi, pembelajaran, tampilan dan pemrograman dengan validasi ahli materi dan ahli media. Pada tahap implementasi kelayakan ditinjau dari aspek kemenarikan, kemudahan penggunaan dan kejelasan yang dinilai oleh anak. Metode penelitian ini adalah metode penelitian dan pengembangan R\&D dengan model desain pembelajaran ADDIE yaitu (1) Analisis (2) Desain (3) Development (Pengembangan) (4) Implementasi (5) Evaluasi. Hasil kelayakan multimedia diperoleh data hasil rerata validasi ahli materi adalah 0,90 dengan kategori "sangat tinggi" dan hasil rerata validasi ahli media adalah 0,94 dengan kategori "sangat tinggi". Hasil implementasi di PAUD Mutiara Kasih Kebumen ditinjau dari aspek kemenarikan, kemudahan dan kejelasan produk multimedia dengan hasil rerata uji lapangan masing-masing aspek adalah 93,3\% dengan kategori "sangat tinggi". Berdasarkan hasil validasi ahli materi dan ahli media serta uji coba lapangan tersebut disimpulkan bahwa produk multimedia pembelajaran menggunakan progam adobe flash CS 6 layak digunakan dalam proses pembelajaran mengenal konsep dan lambang bilangan untuk PAUD.
\end{abstract}

Kata Kunci: Multimedia Pembelajaran, Adobe Flash, ADDIE, Konsep dan Lambang Bilangan,

\begin{abstract}
Multimedia Learning Development Using Adobe Flash Knowing Concepts And Deads. This study aims to produce multimedia products to recognize the concept and symbol of PAUD numbers are feasible to use in the learning process. The feasibility of multimedia learning in terms of material aspects, learning, display and programming with validation of material experts and media experts. In the implementation phase of feasibility in terms of attractiveness, ease of use and clarity assessed by the child. This research method is research and development method of $\mathrm{R}$ \& D with ADDIE learning design model that is (1) Analysis (2) Design (3) Development (4) Implementation (5) Evaluation. The result of the feasibility of multimedia data obtained from the average validation of material experts is 0.90 with the category "very high" and the average media expert validation is 0.94 with the category "very high". The result of implementation in PAUD Mutiara Kasih Kebumen viewed from the aspect of attractiveness, easiness and clarity of multimedia product with the average field test result of each aspect is 93,3\% with "very high" category. Based on the results of validation of material experts and media experts and field trials concluded that multimedia learning products using adobe flash CS6 program is feasible to be used in the learning process to know the concept and symbol of the numbers for early childhood.
\end{abstract}

Keywords: Learning Multimedia, Adobe Flash, ADDIE, Concept and Number Symbol 
Pendidikan adalah hak warga negara, tidak terkecuali pendidikan di usia dini merupakan hak warga negara dalam mengembangkan potensinya sejak dini. Berdasarkan berbagai penelitian bahwa usia dini merupakan pondasi terbaik dalam mengembangkan kehidupannya di masa depan. Selain itu pendidikan di usia dini mengembangkan potensi anak sejak usia dini sebagai persiapan untuk hidup, menyesuaikan diri dengan lingkungannya dan mempersiapkan diri untuk memasuki pendidikan selanjutnya (Dian Anggraeni, 2014: 56).

PAUD pada hakikatnya merupakan pendidikan yang diselenggarakan dengan tujuan untuk memfasilitasi pertumbuhan anak secara menyeluruh atau menekankan pada pengembangan seluruh aspek kepribadian anak. Setiap tahap perkembangan anak usia dini memiliki ciri atau tugas perkembangan tertentu yang dapat dijadikan standar atau perkiraan tentang hal-hal yang harus dikuasai anak pada tahap tertentu (Desak dkk, 2014: 2). Standar perkembangan anak dijabarkan secara rinci dalam Permendikbud No 137 Tahun 2014 tentang standar PAUD dalam bab standar tingkat pencapaian perkembangan yang terdiri dari lingkup perkembangan nilai-nilai agama dan moral, motorik kasar dan motorik halus, kognitif, bahasa serta sosial-emosional. Standar tingkat pencapaian perkembangan tersebut disusun berdasarkan kelompok usia anak mulai dari 0- $<2,2-<4$ dan $4-\leq 6$ tahun.

\section{Berdasarkan observasi di PAUD} Mutiara Kasih Kebumen pada tanggal 7 April 2016 terlihat dalam proses pembelajaran, guru mengajarkan materi mengenal konsep dan lambang bilangan dengan cara menghubungkan konsep bilangan dengan lambang bilangan 1-10. Salah satu contoh hal yang dilakukan guru adalah dengan mengenalkan konsep angka lima, guru menggunakan lima buah spidol sebagai alat peraga. Guru mulai mengajak anak menghitung spidol. Setelah anak menyebutkan jumlah semua spidol kemudian guru menuliskan lambang bilangan dari angka lima di papan tulis dan anak selanjutnya mengikuti cara guru dalam menulis lambang bilangan angka lima tersebut pada kertas yang telah disediakan sebelumnya. Jalannya proses pembelajaran kurang mendapat perhatian dari anak-anak. Hal tersebut terlihat saat pembelajaran berlangsung, beberapa anak terlihat melakukan aktivitas sendiri yang tidak berkaitan dengan pembelajaran yang diajarkan, yaitu: membuat gambar-gambar di kertas, memainkan pensil, berlari-lari, menggangu teman sehingga menimbulkan pertengkaran dan berakhir dengan ada yang anak yang menangis. Kurangnya perhatian anak dalam proses pembelajaran membuat siswa mengalami kebingungan. Siswa dapat menuliskan lambang angka lima tetapi siswa kurang memahami mengapa mereka disuruh untuk menghitung spidol dan kurang memahami juga hubungan antara banyaknya spidol dengan simbol angka lima.

Berdasarkan dari observasi tersebut maka guru dan peneliti bersepakat tentang perlunya perbaikan dalam usaha menarik perhatian anak untuk mengenal konsep dan lambang bilangan sehingga tujuan pembelajaran dapat tercapai secara optimal. Salah satu usaha perbaikan yang dilakukan adalah dengan mengunakan media pembelajaran yang tepat dalam proses pembelajaran karena dapat menarik dan memotivasi siswa dalam belajar. Penggunaan media pembelajaran yang tepat sangat diperlukan dalam proses pembelajaran sesuai dengan pernyataan Hamalik yang mengemukakan bahwa pemakaian media pembelajaran dalam proses belajar mengajar dapat membangkitkan keinginan dan minat yang baru, membangkitkan motivasi dan rangsangan kegiatan belajar, dan membawa pengaruh-pengaruh psikologis terhadap siswa (AzharArsyad, 2010: 15).

Dunia pendidikan saat ini telah banyak sekali mengalami perubahan baik dari segi muatan kurikulum sampai dengan penggunaan 
media yang digunakan dalam proses pembelajaran. Media yang digunakan tidak hanya papan dan alat tulis saja, tetapi juga media yang relatif lebih baru, yang diharapkan dapat menunjang proses pembelajaran. Salah satu alternatif media yang dapat diintegrasikan dalam proses pembelajaran adalah media yang berbasis teknologi (Hendra, 2014: 24). Komputer sebagai salah satu produk teknologi dinilai tepat digunakan sebagai alat bantu pembelajaran dan memiliki potensi yang cukup besar untuk dapat dimanfaatkan dalam proses pembelajaran. Dengan menggunakan salah satu media lunak (software) komputer adobe flash, guru dapat mengembangkan media pembelajaran berbasis multimedia yang mampu menampilkan berbagai komponen media, yaitu: video, data, gambar, teks, animasi, game dan suara sehingga dapat merangsang lebih banyak indra. Melalui komponen multimedia tersebut dapat ditampilkan kejadian nyata yang berkaitan dengan materi yang dipelajari sehingga pembelajaran menjadi lebih kontekstual dan menarik sehingga anak termotivasi dan tertarik dalam mempejari materi yang diajarkan.

Terkait penggunaan adobe flash untuk multimedia pembelajaran dalam penelitian dikemukakan oleh Rini Sovia (2011) tentang Pembuatan Aplikasi Pembelajaran Berhitung bagi Anak Playgroup Menggunakan Metode Menghitung Gambar dengan Menerapkan Bahasa Pemograman Macromedia Flash 8 mengungkapkan bahwa metode menghitung gambar dengan menggunakan Macromedia Flash 8 dapat dijadikan multimedia pembelajaran dan membantu orang tua mengarahkan anak untuk menggunakan komputer sebagai sarana pembelajaran.

Penelitian lainnya yang dilakukan oleh Jamaludin dan Stefanus Santosa (2011) yang berjudul Model Pembelajaran Proses Terjadinya Hujan pada Pendidikan Anak Usia Dini (PAUD) Berbasis Multimedia mengungkapkan bahwa penggunaan media pembelajaran menarik sehingga materi pembelajaran dapat mudah dipahami dan produk multimedia pembejaran memenuhi unsur-unsur pembuatan produk mutimedia yaitu informasi penarik perhatian, materi pembelajaran, simulasi, visualisasi, dan evaluasi.

Penelitian sejenis juga dilakukan oleh Rizqi dkk (2015) dengan judul Perancangan Media Pembelajaran Berhitung Berbasis Multimedia Flash menunjukan bahwa dengan multimedia flash memungkinkan pemakai komputer untuk mendapatkan output dalam bentuk yang jauh lebih kaya daripada media pembelajaran manual konvensional. Pemakai dapat melihat gambar tiga dimensi, foto, video bergerak, atau animasi, dan mendengar suara stereo, dan perekaman suara, atau musik.

Uraian latar belakang di atas menunjukan bahwa penggunaan adobe flash dalam mengembangkan multimedia pembelajaran sudah banyak dilakukan dan hasil pengembangan tersebut layak dijadikan media pembelajaran. Berdasarkan pada hal tersebut maka penelitian kami bertujuan untuk menghasilkan produk multimedia pembelajaran mengenal konsep dan lambang bilangan yang layak bagi anak usia dini dalam materi mengenal konsep dan lambang bilangan

\section{METODE}

Metode penelitian yang digunakan dalam penelitian ini adalah metode penelitian dan pengembangan (Reseach and Development/ $R \& D$ ) dengan Model pengembangan terdiri atas lima tahapan yaitu Analisis, Desain, Development (pengembangan) dan Evaluasi (ADDIE) (Gafur, 2012: 38) yang dijabarkan sebagai berikut.

1. Analisis

Mengumpulkan informasi tentang halhal yang menjadi landasan pengembangan multimedia pembelajaran. tahapan analisis 
dilakukan dengan menggunakan teknik wawancara dan observasi

2. Desain

Tahap desain yaitu pembuatan draft produk multimedia pembelajaran. Draft ini akan berguna untuk membuat flowchart. Selanjutnya dari flowchart dibuat storyboard yang bisa menjadi dasar untuk membuat produk multimedia pembelajaran.

3. Development (pengembangan)

Tahap pengembangan yaitu dengan membuat produk awal, kemudian produk tersebut divalidasi oleh satu ahli materi dan satu ahli media. Produk yang telah divalidasi kemudian direvisi sesuai dengan yang disarankan. Kemudian produk multimedia pembelajaran siap diujicobakan kepada anak.

4. Implementasi

Tahap implementasi yaitu produk yang telah direvisi sesuai saran ahli materi dan ahli media dan dinyatakan layak untuk diuji cobakan. Uji coba ini dilakukan menjadi tiga tahap yaitu uji coba anak peranak, uji coba kelompok kecil dan uji coba lapangan atau kelompok besar.

5. Evaluasi

Tahap evaluasi dapat terjadi pada setiap empat tahap di atas. Evaluasi yang terjadi pada setiap empat tahap diatas itu dinamakan evaluasi formatif, karena tujuannya untuk kebutuhan revisi. Revisi oleh ahli materi dan ahli media yang dilakukan sebanyak dua kali menggunakan angket validasi media dan angket validasi materi, serta menggunakan angket respon anak untuk mengetahui respon anak terhadap multimedia pembelajaran yang telah dibuat.

\section{Desain Uji Coba Produk}

Uji coba produk dilakukan pada tahap implementasi dengan tujuan untuk mendapatkan data mengenai respons anak terhadap media pembelajaan yang sudah dikembangkan dan divalidasi oleh ahli materi dan ahli media ditinjau dari aspek kemenarikan, kemudahan penggunaan dan kejelasan produk.

Desain uji coba produk dilakukan dalam tiga tahap evaluasi formatif (Gafur, 2012: 33) yaitu

1. Uji coba satu lawan satu

Melibatkan 3 anak secara individual, anak yang dipilih adalah anak dengan perkembangan kognitif kurang, sedang dan tinggi evaluasi bertujuan untuk mengidentifikasi kekurangankekurangan yang terdapat dalam produk multimedia dan mendapatkan respons anak tentang isi dan materi pembelajaran.

\section{Uji coba kelompok kecil}

Berdasarkan hasil analisis dan revisi uji coba satu lawan satu maka produk multimedia kembali diujicobakan pada kelompok kecil. Melibatkan 5 anak secara acak. Diharapkan anak-anak memberikan penilaian terhadap produk multimedia berupa kritik dan saran perbaikan sehingga produk yang dikembangankan memenuhi kriteria yang ditetapkan yaitu mengenai kemenarikan produk multimedia, interaktivitas dan kemudahan penggunaan produk multimedia.

\section{Uji coba lapangan}

Berdasarkan hasil analisis dan revisi uji coba kelompok kecil maka produk multimedia kembali diujicobakan pada kelompok besar. Uji lapangan ini dilakukan kepada semua anak di PAUD Mutiara Kasih Kebumen yang berjumlah 15 orang dengan tujuan untuk menentukan apakah produk multimedia yang dikembangkan telah layak digunakan sebagai media pembelajaran atau tidak. 


\section{Teknik Pengumpulan Data}

Teknik yang digunakan untuk mengumpulkan data adalah teknik non tes yang terdiri dari wawancara, observasi dan angket. Teknik wawancara dan observasi dilakukan untuk memperoleh data kualitatif berupa informasi yang tepat mengenai studi pustaka dan studi lapangan sebelum melakukan produksi multimedia pembelajaran, sedangkan angket dilakukan untuk mengetahui data kuantitatif tentang kelayakan multimedia pembelajaran dilihat dari aspek pembelajaran, isi materi, tampilan dan pemograman yang divalidasi oleh ahli materi dan ahli media serta aspek kemenarikan, kemudahan penggunaan dan kejelasan produk yang dinilai oleh anak.

Observasi digunakan dengan lembar observasi terstruktur untuk mengetahui keadaan PAUD Mutiara Kasih Kebumen sebagai tempat uji coba produk multimedia mulai dari kurikulum, pengetahuan awal anak, metode dan strategi pembelajaran, persiapan guru dalam melakukan proses pembelajaran serta sarana dan prasarana yang ada. Wawancara dilakukan untuk mengumpulkan data dari anak dan guru sebagai pendukung data hasil observasi.

Angket digunakan untuk pengumpulan data kuantitatif. Terdapat dua jenis angket yaitu angket yang diserahkan kepada ahli materi dan ahli media dengan menggunakan skala Likert dan angket yang diberikan kepada anak-anak dengan menggunakan skala Guttman. Angket untuk ahli materi untuk mendapatkan data tentang kelayakan program yang dikembangkan ditinjau dari aspek pembelajaran dan aspek isi materi. Angket untuk ahli media untuk mendapatkan data tentang kelayakan program yang dikembangkan ditinjau dari aspek tampilan dan aspek pemrograman sedangkan angket yang diberikan kepada anak-anak bertujuan untuk mengetahui respons anak-anak terhadap produk multimedia yang dihasilkan berdasarkan kemenarikan, kemudahan penggunaan dan kejelasan produk menurut anak-anak ketika melakukan uji produk.

\section{Teknik Analisis Data}

Teknik analisis kelayakan produk multimedia pembelajaran dilakukan setelah data angket terkumpul. Angket yang diserahkan kepada ahli materi dan ahli media dengan menggunakan skala Likert dilakukan dengan analis sebagai berikut (Sugiyono, 2012: 137).

1. Menghitung jumlah skor kriterium

Skor kriterium merupakan skor jika setiap butir mendapatkan skor tertinggi dengan rumusan skor tertinggi dikalikan dengan jumlah butir pernyataan dan jumlah responden.

2. Menghitung jumlah skor hasil pengumpulan data

Skor-skor yang diperoleh dari responden, ditabulasikan dalam tabel dan dihitung jumlah keseluruhan skor data kuantitatif yang dipilih seluruh responden

3. Menentukan kategori atau interpretasi data

Setelah diketahui jumlah skor kriterium dan jumlah skor hasil pengumpulan data, dihitung skor kualitas dengan cara jumlah skor hasil pengumpulan data dibagi dengan skor kriterium kemudian dikalikan $100 \%$ Sehingga diketahui presentasi dan kriteria yang ditetapkan, kemudian data hasil angket dibuat klasifikasi dengan kriteria seperti pada tabel (Sugiyono, 2012: 99)

Tabel 1

Kriteria Kelayakan Produk Multimedia Berdasarkan Skala Likert

\begin{tabular}{|c|c|}
\hline Presentase & Kriteria \\
\hline $75 \%-100 \%$ & Sangat Tinggi/Layak \\
\hline $50 \%-74,99 \%$ & Tinggi/Layak \\
\hline $25-49,99 \%$ & Sedang \\
\hline $0-24,99 \%$ & Rendah/Kurang Layak \\
\hline
\end{tabular}


Angket yang diberikan kepada anakanak dengan menggunakan skala Guttman dilakukan dengan analis sebagai berikut:

1. Berdasarkan pedoman penskoran yang telah dibuat, dihitung jumlah skor tiaptiap hasil pengamatan yaitu "ya" dan "tidak" untuk masing-masing peserta didik

2. Hasil penjumlahan semua skor "ya" dan "tidak" kemudian dipresentasekan untuk membuat kesimpulan mengenai kemenarikan, kemudahan penggunaan dan kejelasan produk menurut anak.

Adapun rumus data presentase kelayakan multimedia pembelajaran yang didasarkan pada aspek kemenarikan, kemudahan dalam penggunaan dan kejelasan dalam tampilan dan suara adalah sebagai berikut (Anas Sudjono, 2013: 43):

$$
P=f / N \times 100 \%
$$

Dimana :

$\mathrm{P}=$ angka presentase,

$\mathrm{F}=$ frekuensi yang sedang dicari presentasinya $\mathrm{N}$ = banyaknya individu.

Sehingga diketahui presentasi dan kriteria yang ditetapkan, kemudian data hasil angket dibuat klasifikasi dengan kriteria seperti pada tabel 1

\section{HASIL DAN PEMBAHASAN}

Tahapan analisis yang pertama adalah studi pustaka, data yang diperoleh dari kegiatan ini adalah Saat ini banyak sekali pemanfaatan software komputer yang dapat digunakan sebagai media pembelajaran berbasis multimedia dan salah satu software yang banyak digunakan adalah adobe flash, Standar tingkat pencapaian perkembangan anak usia 3-6 tahun dalam lingkup perkembangan konsep dan lambang bilangan adalah menyebutkan lambang bilangan 1-10 dan mencocokan bilangan dengan lambang bilangan. standar tingkat pencapaian perkembangan anak usia dini dapat dilihat dalam permendikbud nomor 137 tahun 2014 tentang standar pendidikan anak usia dini, dan Penggunaan media pembelajaran berbasis multimedia memberikan pemahaman yang lebih baik dibandingkan dengan media pembelajaran konvensional atau sederhana.

Tahapan kedua adalah studi lapangan, data yang diperoleh dari kegiatan ini adalah (1) guru-guru sudah mampu mengoperasikan komputer atau laptop dalam kegiatan sehari-hari (2) sekolah sudah memiliki fasilitas yang dapat digunakan untuk pemanfaatan media pembelajaran berbasis multimedia seperti laptop dan speaker aktif tetapi pemanfaatannya masih sebatas untuk keperluan administratif dan kegiatan olahraga anak (3) tingkat pemahaman anak terhadap materi pembelajaran bervariasi. Bagi anak yang tingkat pemahamannya cukup tinggi mereka aktif bertanya dan antusias dalam proses pembelajaran sedangkan bagi anak yang tingkat pemahamannya kurang merekasering melakukan aktivitas lain yang

Tidak berhubungan dengan proses pembelajaran (4) Media pembelajaran yang dugunakan masih media pembelajaran konvensional seperti papan tulis, kertas, gambar dan benda-benda yang terdapat di sekitar sekolah (5) Sebagain besar anak mengalami kesulitan dalam mengenal konsep dan lambang bilangan.

Hasil data yang diperoleh dari studi pustaka dan studi lapangan selanjutnya dijadikan bahan pertimbangan dan masukan untuk mendesain dan mengembangkan produk multimedia pembelajaran mengenal konsep dan lambang bilangan. Setelah dikembangkan maka produk multimedia kemudian divalidasi oleh ahli materi dan ahli media untuk menilai kelayakan multimedia yang telah dikembangkan untuk diujicobakan atau 
diimplementasikan. Penilaian ahli materi didasarkan pada aspek materi dan pembelajaran sedangkan penilaian ahli media didasarkan pada aspek tampilan dan pemograman. Validasi ahli materi dan ahli media dilakukan sebanyak dua kali yaitu (1) ketika produk pertama kali dikembangkan (2) ketika revisi produk atas saran dan masukan dari ahli materi dan ahli media.

\section{Hasil Perbandingan Validasi Ahli Materi Sebelum dan Sesudah Revisi}

Validasi ahli materi dilakukan untuk mengetahui kualitas produk multimedia pembelajaran ditinjau dari aspek materi dan pembelajaran yang terdiri dari 8 butir dan 12 butir pernyataan. Hasil perbandingan validasi ahli materi sebelum dan sesudah revisi dapat dilihat dari grafik berikut.

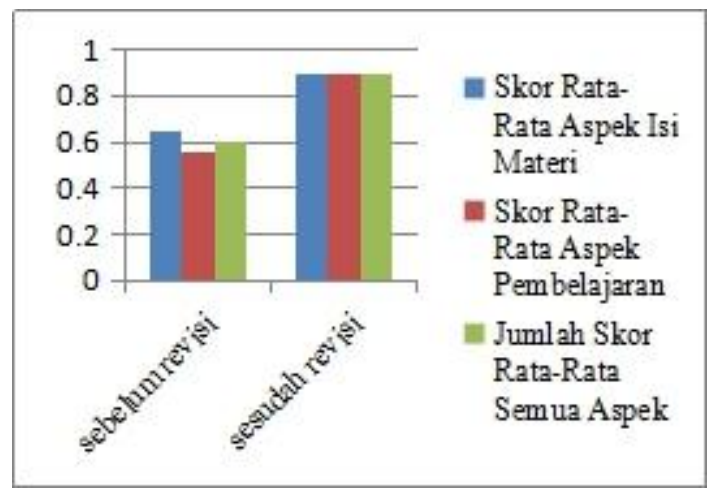

\section{Gambar 1}

\section{Grafik Hasil Perbandingan Validasi Ahli Materi Sebelum dan Sesudah Revisi}

Berdasarkan grafik di atas, diperoleh data tentang jumlah rata-rata skor validasi ahli materi sebelum revisi adalah 0,605 dan setelah direvisi adalah 0,9. Hal tersebut menunjukan bahwa multimedia pembelajaran yang dikembangkan dilihat dari aspek isi materi dan aspek pembelajaran "sangat layak" untuk diujicobakan pada tahap implementasi.

\section{Hasil Validasi Ahli Media}

Validasi ahli media dilakukan untuk mengetahui kualitas produk multimedia pembelajaran ditinjau dari aspek tampilan dan pemograman yang terdiri dari 14 dan 10 butir pernyataan. Hasil perbandingan validasi ahli media sebelum dan sesudah revisi dapat dilihat dari grafik berikut.

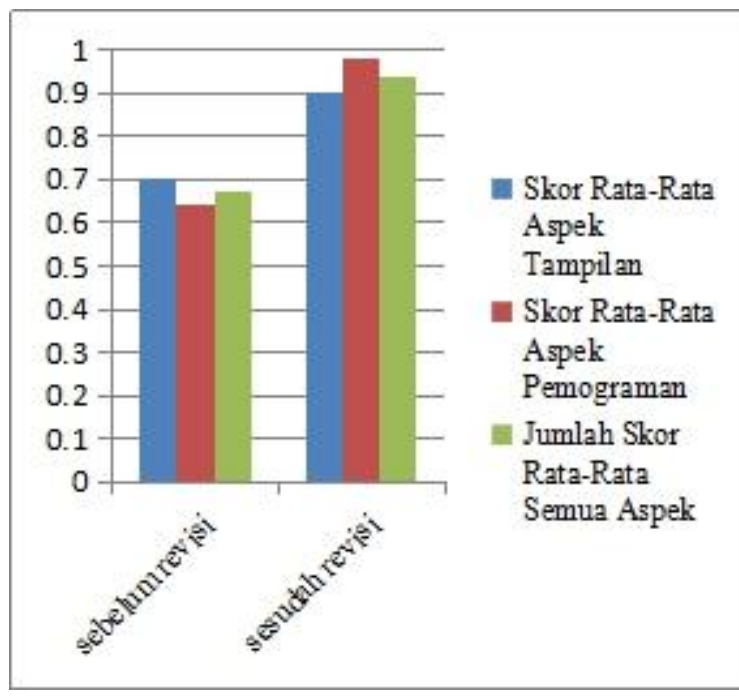

Gambar 2

\section{Grafik Hasil Perbandingan Validasi Ahli Materi Sebelum dan Sesudah Revisi}

Berdasarkan grafik di atas, diperoleh data tentang jumlah rata-rata skor validasi ahli media sebelum revisi adalah 0,67 dan setelah direvisi adalah 0,94 . Hal tersebut menunjukan bahwa multimedia pembelajaran yang dikembangkan dilihat dari aspek tampilan dan aspek pemograman "sangat layak" untuk diujicobakan pada tahap implementasi.

Tampilan Media Setelah Revisi

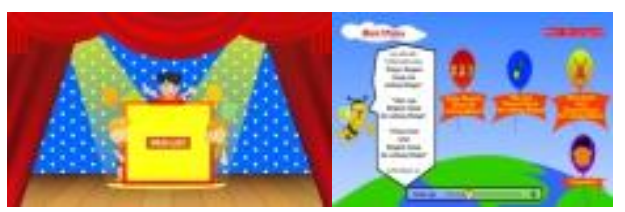

Gambar 3

\section{Tampilan Awal dan Menu Utama}

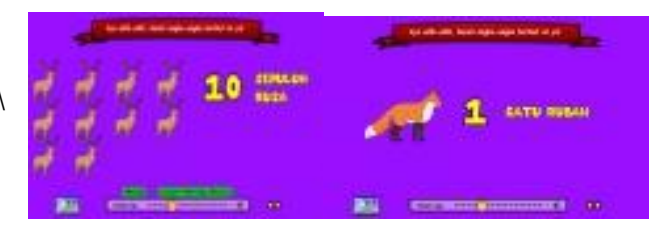

Gambar 4

Tampilan Menu Belajar Mengenal Konsep dan Lambang Bilangan 


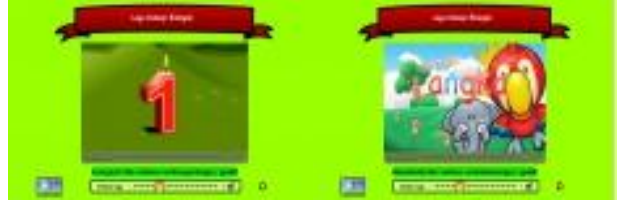

Gambar 5

Tampilan Menu Video Lagu Mengenal Konsep dan Lambang Bilangan

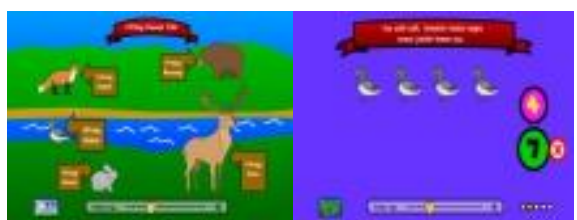

Gambar 6

Tampilan Menu Hitung Hewan untuk Mengenal Konsep dan Lambang Bilangan

\section{Hasil Uji Coba Satu Lawan Satu}

Uji coba satu lawan satu dilaksanakan untuk mendapatkan data empiris mengenai kelayakan media pembelajaran berbasis multimedia mengenal konsep dan lambang bilangan yang sudah melalui uji kelayakan dari ahli materi dan ahli media. Uji coba dilakukan dengan responden 3 orang anak dengan kemampuan kognitif yang berbeda didasarkan pada penilaian guru pendamping. Uji coba dilakukan dengan menunjukan produk dan menjelaskan secara singkat aplikasi penggunaan media pembelajaran berbasis multimedia kepada anak-anak dan kemudian anak memberikan tanggapan mengenai kulitas produk dari segi kemudahan, kemenarikan dan kejelasan media tersebut. Hasil penilaian anak-anak adalah sebagai berikut.

Tabel 2

Rerata Uji Coba Satu Lawan Satu

\begin{tabular}{|l|l|c|c|c|c|l|}
\hline No & $\begin{array}{l}\text { Aspek } \\
\text { Penilaian }\end{array}$ & \multicolumn{1}{|c|}{ Anak } & $\mathbf{2}$ & $\mathbf{3}$ & & Kategori \\
\cline { 2 - 6 } & Kemenarikan & 1 & 1 & 1 & 100 & $\begin{array}{l}\text { Sangat } \\
\text { layak }\end{array}$ \\
\hline 2. & $\begin{array}{l}\text { Kemudahan } \\
\text { menggunakan } \\
\text { media dan belajar }\end{array}$ & 1 & 1 & 1 & 100 & $\begin{array}{l}\text { Sangat } \\
\text { layak }\end{array}$ \\
\hline 3. & $\begin{array}{l}\text { Kejelasan dan } \\
\text { tampilan } \\
\text { suara }\end{array}$ & 1 & 1 & 1 & 100 & $\begin{array}{l}\text { Sangat } \\
\text { layak }\end{array}$ \\
\hline
\end{tabular}

Berdasarkan tabel di atas diketahui bahwa rata-rata hasi uji coba satu lawan satu adalah $100 \%$ dengan kategori "sangat tinggi" untuk semua aspek penilaian. Aspek penilaian pertama yaitu tentang kemenarikan atau kesukaan terdiri dari kemenarikan media dan materi yang dikembangkan. Aspek penilaian kedua yaitu tentang kemudahan dalam menggunakan media dan belajar terdiri dari kemudahan menggunakan media dan kemudahan memahami materi. Aspek penilaian ketiga yaitu tentang kejelasan tampilan dan suara media pembelajaran. Penilian hasil rata-rata uji coba satu lawan satu dengan kategori "sangat tinggi" tersebut dapat dijadikan penarikan kesimpulan bahwa proses uji coba dapat dilanjutkan ke tahap berikutnya yaitu uji coba kelompok kecil tanpa harus melakukan revisi media pembelajaran berbasis multimedia yang telah dikembangkan

\section{Hasil Uji Coba Kelompok Kecil}

Uji coba dilaksanakan dengan responden 5 orang anak. Uji coba dilakukan dengan menunjukan produk dan menjelaskan secara singkat aplikasi penggunaan media pembelajaran berbasis multimedia kepada anak-anak dan kemudian anak memberikan tanggapan mengenai kulitas produk dari segi kemudahan, kemenarikan dan kejelasan media tersebut. Hasil penilaian anak-anak adalah sebagai berikut.

Tabel 3

Rerata Uji Coba Kelompok Kecil dengan 5 Anak

\begin{tabular}{|l|l|c|l|}
\hline No & Aspek Penilaian & $\begin{array}{c}\text { Rata-Rata } \\
\text { Persentase } \\
(\boldsymbol{\%})\end{array}$ & Kategori \\
\hline 1. & $\begin{array}{l}\text { Kemenarikan } \\
2 .\end{array}$ & $\begin{array}{l}\text { Kemudahan } \\
\text { menggunakan } \\
\text { media } \\
\text { belajar dan }\end{array}$ & $\begin{array}{l}\text { Sangat } \\
\text { layak }\end{array}$ \\
\hline 3. & $\begin{array}{l}\text { Kejelasan } \\
\text { tampilan dan } \\
\text { suara }\end{array}$ & $\begin{array}{l}\text { Sangat } \\
\text { layak }\end{array}$ \\
\hline
\end{tabular}


Berdasarkan tabel di atas , maka hasil penilaian anak terhadap media pembelajaran berbasis multimedia mengenal konsep dan lambang bilangan pada uji coba kelompok kecil masuk dalam kategori "sangat tinggi" dengan persentase $100 \%$. Maka dapat ditarik kesimpulan bahwa proses uji coba produk dapat dilanjutkan pada tahap akhir yaitu uji coba lapangan.

\section{Hasil Uji Coba Lapangan}

Uji coba lapangan dilakuk dengan responden 15 orang anak. Uji coba dilakukan dengan cara mengelompokan anak menjadi 3 kelompok yang masing-masing kelompok terdiri dari 5 oran anak. Uji coba dilakukan dengan menunjukan produk dan menjelaskan secara singkat aplikasi penggunaan media pembelajaran berbasis multimedia kepada anak-anak dan kemudian anak memberikan tanggapan mengenai kulitas produk dari segi kemudahan, kemenarikan dan kejelasan media tersebut. Hasil penilaian anak-anak adalah sebagai berikut.

\section{Tabel 4}

Rerata Uji Coba Lapangan

\begin{tabular}{|l|l|c|c|c|c|}
\hline No & \multicolumn{1}{|c|}{$\begin{array}{c}\text { Aspek } \\
\text { Penilaian }\end{array}$} & \multicolumn{2}{|c|}{$\begin{array}{c}\text { Skor } \\
\text { Penilaian }\end{array}$} & $\mathbf{( \% )}$ & Kategori \\
\cline { 2 - 4 } & & $\mathbf{1}$ & $\mathbf{0}$ & & \\
\hline 1. & Kemenarikan & 28 & 1 & 93,3 & $\begin{array}{c}\text { Sangat } \\
\text { layak }\end{array}$ \\
\hline 2. & $\begin{array}{l}\text { Kemudahan } \\
\text { menggunakan } \\
\text { media dan } \\
\text { belajar }\end{array}$ & 30 & 0 & 100 & $\begin{array}{c}\text { Sangat } \\
\text { layak }\end{array}$ \\
\hline 3. & $\begin{array}{l}\text { Kejelasan dan } \\
\text { tampilan dan } \\
\text { suara }\end{array}$ & 26 & 2 & 86,6 & $\begin{array}{c}\text { Sangat } \\
\text { layak }\end{array}$ \\
\hline
\end{tabular}

Berdasarkan tabel di atas, maka hasil penilaian anak terhadap media pembelajaran berbasis multimedia mengenal konsep dan lambang bilangan pada uji coba lapangan masuk dalam kategori "sangat layak" dengan persentase 93,3\%. Pada aspek kemenarikan atau kesukaan terdapat 1 anak menyatakan ketidakmenarikan atau ketidaksukaan tentang produk media yang telah dikembangkan. Pada aspek kemudahan dalam menggunakan media dan belajar semua anak menyatakan bahwa produk media yang dikembangkan mudah digunakan dan materinya mudah dipahami. Pada aspek kejelasan tampilan dan suara terdapat 2 anak menyatakan bahwa produk media yang dikembangkan memiliki tampilan dan suara tidak jelas.

Data tersebut menunjukan bahwa produk multimedia yang dikembangkan dalam penelitian ini "sangat layak" digunakan sebagai salah satu alternatif media pembelajaran dalam materi mengenal konsep dan lambang bilangan. Pengembangan poduk multimedia tepat digunakan pada pendidikan anak usia dini yang lebih membutuhkan media-media pembelajaran bersifat kongkrit dan nyata. Hal tersebut sesuai dengan pernyataan Hamalik bahwa Penggunaan media pembelajaran yang tepat sangat diperlukan dalam proses pembelajaran sesuai karena dapat membangkitkan keinginan dan minat yang baru, membangkitkan motivasi dan rangsangan kegiatan belajar, dan membawa pengaruhpengaruh psikologis terhadap siswa (AzharArsyad, 2010: 15).

\section{SIMPULAN}

Berdasarkan hasil penelitian diperoleh data sebagai berikut : (1) jumlah skor rata-rata validasi ahli materi adalah 0,9 atau 90 $\%$ dengan kategori "sangat layak" (2) jumlah skor rata-rata validasi ahli media adalah 0,94 atau 94\% dengan kategori "sangat layak" (3) jumlah skor rata-rata hasil uji coba lapangan adalah 93,3\% dengan kategori "sangat layak". Data-data tersebut menyimpulkan bahwa produk multimedia yang dikembangkan "layak" digunakan dalam proses pembelajaran mengenal konsep dan lambang bilangan anak usia dini. 
Saran

Saran yang dapat diberikan adalah (1) sekolah, hendaknya mulai memanfaatkan media pembelajaran berbasis multimedia dalam proses pembelajaran (2) anak, hendaknya belajar terus menerus secara baik di sekolah maupun di rumah dengan meminta bimbingan kepada guru dan orang tua agar pemahaman tentang konsep dan lambang bilangan semakin baik setiap harinya, (3) guru dan orang tua, hendaknya mendampingi anak dalam memanfaatkan produk multimedia yang telah dikembangkan agar dapat mengetahui perkembangan belajar anak dalam memahami konsep dan lambang bilangan.

\section{DAFTAR PUSTAKA}

Asyad, A.2010. Media Pembelajaran. Jakarta: PT Raja Grafindo Persada

Gafur, A.2012. Desain Pembelajaran: Konsep, Model, Aplikasinya dalam Perencanaan Pelaksanaan Pembelajaran. Yogyakarta:Ombak.

Jamaludin dan Santosa, S. 2011. Model Pembelajaran Proses Terjadinya Hujan pada Pendidikan Anak Usia Dini (PAUD) Berbasis Multimedia. Jurnal Teknologi Informasi edisi Oktober Vol. 7 No. 2 pp154-166.

Kartika, H. 2014. Pembelajaran Matematika Berbantuan Software MATLAB sebagai Upaya Meningkatkan Kemampuan Komunikasi Matematis dan Minta Belajar Siswa SMA. Jurnal Pendidikan Uniska edisi November Vol 2 No. 1 pp 24-35.

Kharisma, R., S., Reno, K., dan Andre, C., W. 2015. Perancangan Media Pembelajaran Berhitung Berbasis Multimedia Flash. Jurnal Ilmiah DASI edisi Juni Vol. 16 No. 02 Juni pp 42-47
Sovia, R. 2011. Pembuatan Aplikasi Pembelajaran Berhitung bagi Anak Playgroup Menggunakan Metode Menghitung Gambar dengan Menerapkan Bahasa Pemrograman Macromedia Flash 8. Jurnal Teknologi Informasi \& Pendidikan edisi September Vol. 4 No. 1 pp 77-82.

Sudjono, A. 2012. Pengantar Statistik Pendidikan. Jakarta: Rajawali Pers

Sugiyono.2010.Metode Penelitian Pendidikan: Pendekatan Kuantitatif, Kualitatif dan $R \& D$. Bandung:Alfabeta. 